\title{
Analysing and Comparing Warrantless Tax Inspections and Searches
}

F Moosa*

\section{P.E.R}

Pioneer in peer-reviewed, open access online law publications

Author

Fareed Moosa

Affiliation

University of the Western Cape, South Africa

Email

fmoosa@uwc.ac.za

Date Submission

14 March 2018

Date Revised

19 February 2019

Date Accepted

18 February 2019

Date published

23 April 2019

Editor Dr G Viljoen

How to cite this article

Moosa $\mathrm{F}$ "Analysing and Comparing Warrantless Tax Inspections and Searches" PER / PELJ 2019(22) - DOI http://dx.doi.org/10.17159/17273781/2019/v22i0a5705

\section{Copyright}

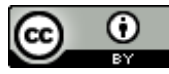

DOI

http://dx.doi.org/10.17159/17273781/2019/v22i0a5705

\begin{abstract}
Sections 45 and 63 of the Tax Administration Act 28 of 2011 (TAA) confer drastic information gathering powers on officials of the South African Revenue Service (SARS). On the one hand, section 45 permits warrantless routine (non-targeted) and nonroutine (targeted) inspections by a SARS official in respect of records, books of accounts and documents found at premises where a taxpayer is reasonably believed to be conducting a trade or enterprise. The purpose of such inspection is to determine whether there has been compliance with specific obligations by the taxpayer. Section 63 , on the other hand, permits, on the grounds of urgency and expediency in exceptional circumstances only, warrantless non-routine (targeted) searches by a senior SARS official of a taxpayer and of third parties associated with a taxpayer, as well as searches of a taxpayer's premises and those of third parties. In addition, section 63 permits the seizure of relevant material found at premises searched. All searches and seizures must occur for the purposes of the efficient and effective administration of tax Acts generally. A comparative analysis of sections 45 and 63 of the TAA reveals the existence of key differences in the substance and practical operation of their provisions. This article distils these differences through an in-depth discussion of the nature and extent of the powers of inspection and search conferred by these provisions, as well as by conceptualising the terms "inspection" and "search" for the purposes of sections 45 and 63 respectively.
\end{abstract}

\section{Keywords}

Tax Administration act; inspections - searches. 
"Knowledge is power. Information is liberating." (Kofi Annan)

\section{Introduction}

The South African Revenue Service Act ${ }^{1}$ (SARS Act) establishes SARS as an organ of state whose aim, as described in section 3, "is the efficient and effective collection of revenue". Unless SARS has access to taxpayers' personal information that would enable it to determine a tax liability, tax collection will suffer. To ensure optimal tax collection, SARS requires powers of investigation, audit, verification, assessment and surveillance through enquiries, inspection and searches. Section 45 of the Tax Administration Act ${ }^{2}$ (TAA) permits warrantless inspections; section 63 authorises warrantless searches. These public powers are potent weapons in SARS's information gathering arsenal, thereby resulting in a powerful tax administration agency with access to information in areas usually considered protected private space. Sections 45 and 63 reads:

45. Inspection. - (1) A SARS official may, for the purposes of the administration of a tax Act and without prior notice, arrive at a premises where the SARS official has a reasonable belief that a trade or enterprise is being carried on and conduct an inspection to determine only -

(a) the identity of the person occupying the premises;

(b) whether the person occupying the premises is registered for tax; or

(c) whether the person is complying with sections 29 and $30 .^{3}$

(2) A SARS official may not enter ${ }^{4}$ a dwelling-house or domestic premises, except any part thereof used for the purposes of trade, under this section without the consent of the occupant....

63. Search without warrant. - (1) A senior SARS official may without a warrant exercise the powers referred to in section 61(3) -

(a) if the owner or person in control of the premises so consents in writing; or

(b) if the senior SARS official on reasonable grounds is satisfied that -

* Dr Fareed Moosa. BProc LLB LLM LLD (UWC). Attorney and Head of the Department of Mercantile and Labour Law, University of the Western Cape, South Africa. E-mail: fmoosa@uwc.ac.za. This article is an extraction of the writer's 2017 LLD thesis: Moosa 1996 Constitution and the Tax Administration Act 28 of 2011: Balancing Efficient and Effective Tax Administration with Taxpayers' Rights.

South African Revenue Service Act 34 of 1997.

Tax Administration Act 28 of 2011.

Section 29 of the TAA obliges a person to keep "records, books of account or documents" that "enable the person to observe the requirements of a tax Act" and "enable SARS to be satisfied that the person has observed these requirements". Section 30 prescribes the form in which the records, books of account and documents concerned are to "be kept or retained".

$4 \quad$ "Enter" is undefined in the TAA. Cohen Commissioner's Powers to Access Information 23 explains its dictionary meaning to be "go into a place". It is submitted that "enter" does not include the use of force or clandestine means to gain entry to premises for TAA purposes. 
(i) there may be an imminent removal or destruction of relevant material likely to be found on the premises;

(ii) if SARS applies for a search warrant under section 59 , a search warrant will be issued; and 5

(iii) the delay in obtaining a warrant would defeat the object of the search and seizure.

(2) A SARS official must, before carrying out the search, inform the owner or person in control of the premises -

(a) that the search is being conducted under this section; and

(b) of the alleged failure to comply with an obligation imposed under a tax

Act or tax offence that is the basis for the search. ${ }^{6}$

(3) Section 61(4) to (8) applies to a search conducted under this section.

(4) A SARS official may not enter a dwelling-house or domestic premises, except any part thereof used for purposes of trade, under this section without the consent of the occupant....

\section{Objective and roadmap of the article}

A literature survey ${ }^{7}$ reveals the absence of a comparative analysis of sections 45 and 63. Also, the terms "inspection" and "search" have not been examined in their TAA context. This article will, at its outset, interpret these terms with reference to their purpose and location in the TAA's overall scheme. Establishing their limits is important to determining when SARS's conduct infringes upon or threatens a taxpayer's right to privacy, which is entrenched in SA's Constitution, 1996. The public powers exercisable at inspections and searches will be discussed in this context. Also, the requirements for a lawful search and inspection will be outlined. This is relevant to evaluating when SARS's conduct passes muster. The conclusion will draw together the threads of the discussion to distil key differences in the substance and operation of sections 45 and 63.

\section{Meaning of "inspection" and "search"}

Under section 40, a taxpayer may be selected "for inspection, verification or audit on the basis of any consideration relevant to the proper administration of a tax Act, including on a random or a risk assessment basis". Once a

5 "And" has the effect that $s 63(1)(b)$ (i), (ii) and (iii) is to be read conjunctively (Maphango v Aengus Lifestyle Properties (Pty) Ltd 20123 SA 531 (CC) para 50). The same applies to $s 63(2)(a)$ and (b). Thus, a search is valid only if all the requirements of $s 63(1)(b)$ are met.

6 The provisions of s 63(2) reflect the decision in Ferucci v CSARS 20026 SA 219 (C) 229A-D, 231A-C. Also see Goqwana v Minister of Safety 20161 All SA 629 (SCA) para 18.

$7 \quad$ Moosa 2012 SA Merc LJ 338; Moosa 2012 ITJ 3; Bovijn and Van Schalkwyk 2012 Stell LR 507; Vogelman and Muller 2014 ITJ 12; Keulder 2015 SALJ 819; Clegg Concise Guide; Klue, Arendse and Williams Silke on Tax Administration; Croome and Olivier Tax Administration; Van Dijk $A$ Probe into the Constitutionality of Relevant Sections. 
taxpayer has been selected, a SARS official may then arrive, unannounced, at the taxpayer's premises and, without warrant, conduct an inspection or search. Although undefined for TAA purposes, inspections and searches differ. These terms are not used synonymously or interchangeably. Sections 45 and 63 are important weapons in SARS's armoury to protect and preserve South Africa's tax base and the State's sources of income. To ensure that SARS utilises its section 45 and 63 powers responsibly and in a manner consistent with the Constitution and the legislature's intention, "inspection" and "search must be interpreted within their TAA framework.

\subsection{Inspection: nature and extent}

Section 45 inspections are not aimed at finding a breach of a tax statute. They are geared to gathering information that advances SARS's ability to police compliance with the taxpayer's duties referred to in section 45(1)(b) and (c). The fiscus will suffer losses if persons liable to register for tax fail to do so, or fail to maintain proper, adequate or orderly business records that would hinder the detection of undisclosed income. Therefore, inspections promote optimal tax assessment and collection for public benefit. The public's interest in and benefit from section 45(1)(a) and (b) is that it enables SARS to identify taxpayers more effectively. The public's interest in, and benefit from section 45(1)(c) is that its provisions enable SARS to ensure the availability of adequate records for audits and investigations aimed at revenue determination or estimation, or at verifying proper disclosure of information required under a "tax Act" as defined.

An inspection under section 45 is a preliminary or preparatory fact-finding exercise because facts uncovered may lead to an audit or criminal investigation (section 48), and/or to inquiry proceedings (section 52), and/or to an application for a search warrant (sections 59, 60,61), and/or to a criminal charge (section 234). If non-compliance under section 45(1)(b) or (c) amounts to the commission of an offence under section 234(a) or (e), then a prosecution may ensue. Viewed in this light, a warrantless inspection may provide SARS with a way to uncover evidence of a tax offence without the need to apply for a warrant under section $59(1) .{ }^{8}$

8 Croome and Olivier Tax Administration 117 argue that s 45 cannot be used to search for documents, or to review a taxpayer's records, or to conduct an audit. Keulder 2015 SALJ 845 warns that a warrantless inspection may be used by SARS with improper motives to achieve the goals of $s 63$ without the need to satisfy the stricter requirements for a warrantless search. The risk of SARS abusing its power under ss 45 or 63 for ulterior or nefarious purposes would not justify a constitutional challenge of their provisions. See S v Van Rooyen 20025 SA 246 (CC) para 37; Head of 
The nature and extent of the powers exercisable at inspections are unclear because the TAA is silent on this issue. This necessitates interpretation of "inspection". 9 The starting point is to consider its plain, natural meaning (that is, the meaning it bears in common parlance or ordinary colloquial speech). ${ }^{10}$ This is referred to as grammatical (linguistic) interpretation. ${ }^{11} \mathrm{~A}$ linguistic construction of section 45(1) shows that "inspection" is not utilised there in a technical sense but in its grammatical sense. Linguistically in section 45(1), "inspection" is a noun. The Oxford Thesaurus ${ }^{12}$ defines inspection as a noun meaning "examination, check-up, survey, scrutiny, probe, exploration, observation, investigation, assessment, appraisal, review, evaluation". Inspection cannot, in section 45(1), bear all these meanings. Its meaning must be narrowed by context. This is referred to as contextual interpretation. ${ }^{13}$ Section 45 operates in tandem with section 31 whose subject matter, apparent from its heading, ${ }^{14}$ is "inspection of records". ${ }^{15} \mathrm{~A}$ contextual reading of their respective provisions indicates that

Department: Mpumalanga Department of Education v Hoërskool Ermelo 20102 SA 415 (CC) para 72. Since courts are responsible for preventing the unfair, unauthorised, oppressive and vexatious use of power, a taxpayer ought to challenge the lawfulness of a specific inspection or search (as the case may be).

For the rules of interpretation, see Natal Joint Municipal Pension Fund $v$ Endumeni Municipality 20124 SA 593 (SCA) paras 18-23. Association of Amusement and Novelty Machine Operators $v$ Minister of Justice 19802 SA 636 (A) 660.

11 Grammatical interpretation entails that, in the absence of a legislated meaning or judicial ruling, a word bears its meaning as generally used, which can be ascertained with reference to a dictionary (Bato Star Fishing (Pty) Ltd v Minister of Environmental Affairs and Tourism 20044 SA 490 (CC) paras 88-92; Sasria Ltd v Slabbert Burger Transport (Pty) Ltd 20085 SA 270 (SCA) para 9). Waite, Hollingworth and Marshall Oxford Paperback Thesaurus 443.

Contextual interpretation entails ascribing meaning to words according to their "setting and surrounds" (Standard General Ins v Commissioner for Customs and Excise 20052 SA 166 (SCA) para 25), even though their meaning may be clear and unambiguous (Department of Land Affairs $v$ Goedgelegen Tropical Fruits (Pty) Ltd 20076 SA 199 (CC) para 53). Put differently, words would be meaningless if read in the abstract or isolated from context (Thoroughbred Breeders' Association $v$ Price Waterhouse 20014 SA 551 (SCA) para 12; Novartis v Maphil 20161 SA 518 (SCA) para 28). "In law, context is everything" (Aktiebolaget Hassle $v$ Triomed (Pty) Ltd 20031 SA 155 (SCA) para 1). Contextual interpretation "is not limited to the language of the rest of the statute 'as throwing light of a dictionary kind on the part to be interpreted' and 'often of more importance is the matter of the statute, its apparent scope and purpose and within limits, its background'" (Ahmed v Minister of Home Affairs 2016 JOL 36695 (WCC) para 15).

14 A heading is relevant for interpretation (Botha Statutory Interpretation 80).

15 Section 31 of the TAA reads: "The records, books of account and documents referred to in section $29 \ldots$ must at all reasonable times during the required periods under section 29, be open for inspection by a SARS official in the Republic for the purpose of - (a) determining compliance with the requirements of sections 29 and 30; or (b) an inspection, audit or investigation under Chapter 5." Section 1 defines "document" as "anything that contains a written, sound or pictorial record, or other record of information, whether in physical or electronic form". Section 1 also defines 
inspection under section 45 entails no more than an examination of records, books of account or documents for the purpose of making an objective determination of the facts listed in sections 45(1)(a), (b) and (c). Thus, inspections do not per se take place in relation to premises where such material are kept. The phrase in section 45(1), namely, "to determine only", narrows the purpose for which an inspection may be undertaken. Linguistically, the disjunctive "or" between sub-paragraphs (b) and (c) indicates that the items in the list in section 45(1)(a), (b) and (c) are not stated conjunctively but rather in the alternative. ${ }^{16}$ Therefore, an inspection need be aimed at making only one (not all) of the determinations concerned.

SARS's power to enter premises for inspection purposes does not include the power to search or seize. Section 45 does not refer to the power (i) to conduct any body search, (ii) to remove or seize any item, (iii) to rifle through private possessions, or (iv) to probe for information, whether by inquiry, interrogation or other mode of questioning. SARS is a creation of statute with no inherent powers or competencies. These must stem from an empowering provision in legislation. ${ }^{17}$ Since the aforementioned powers are not mentioned in relation to inspections, they are excluded from section 45 . This renders inspections under the TAA less intrusive than searches thereunder. Sections 31 (b) and 40 of the TAA quoted above differentiate between inspections, audits and investigations. Applying the maxim expressio unius est alterius exclusio, ${ }^{18}$ reference to "inspection" in section 45 excludes audits and investigations. ${ }^{19}$ This interpretation is consonant with an inspection's purpose in sections $45(1)$ read with $3(2),{ }^{20}$ and also best

"information" as including "information generated, recorded, sent, received, stored or displayed by any means". The definition of "document" includes electronic communication per the Electronic Communications and Transactions Act 25 of 2002, discussed in Spring Forest Trading 599 CC v Wilberry (Pty) Ltd t/a Ecowash 20152 SA 118 (SCA).

$16 \quad$ MV Iran Dastghayb Islamic Republic of Iran Shipping Lines V Terra-Marine SA 2010 6 SA 493 (SCA) para 22; Master Currency (Pty) Ltd v CSARS 20133 All SA 135 (SCA) para 15.

$17 \quad$ AM Moolla Group Ltd v CSARS 2005 JOL 15456 (T) 3.

18 Translated as "the expression of one thing is the exclusion of the other".

19 De Ville Constitutional and Statutory Interpretation 131.

20 An inspection must be "for the purposes of the administration of a tax Act". This stipulation is probably not a qualification of the powers in $s 45$. See Gaertner $v$ Minister of Finance 20141 SA 442 (CC) para 38. S 3(2) defines "administration of a tax Act" to mean "to - (a) obtain full information in relation to - (i) anything that may affect the liability of a person for tax in respect of a previous, current or future tax period; (ii) a taxable event; or (iii) the obligation of a person (whether personally or on behalf of another person) to comply with a tax Act; (b) ascertain whether a person has filed or submitted correct returns, information or documents in compliance with the provisions of a tax Act; (c) establish the identity of a person for purposes of determining liability for tax; (d) determine the liability of a person for tax; (e) collect 
advances the attainment of the TAA's broader aims listed in section $2 .{ }^{21}$ This is referred to as purposive interpretation. ${ }^{22}$

An inspection is intrusive of privacy, albeit a lower level invasiveness. ${ }^{23}$ Is a section 45 inspection a "search" under section 14(a) and/or (b) of the Constitution? ${ }^{24}$ If yes, it is a limitation, under section 36(1) of the Constitution, which SARS must justify. ${ }^{25}$. This is a factual question in each instance. Except for regulatory searches, ${ }^{26}$ South African courts have refrained from making a definitive ruling of when an inspection is a

tax debts and refund tax overpaid; (f) investigate whether a tax offence has been committed, and, if so, - (i) to lay criminal charges; and (ii) to provide the assistance that is reasonably required for the investigation and prosecution of the tax offence; (g) enforce SARS' powers and duties under a tax Act to ensure that an obligation imposed by or under a tax Act is complied with; (h) perform any other administrative function necessary to carry out the provisions of a tax Act; (i) give effect to the obligation of the Republic to provide assistance under an international tax agreement; and (j) give effect to an international standard".

21 Section 2 of the TAA reads: "The purpose of this Act is to ensure the effective and efficient collection of tax by - (a) aligning the administration of the tax Acts to the extent practically possible; (b) prescribing the rights and obligations of taxpayers and other persons to whom this Act applies; (c) prescribing the powers and duties of persons engaged in the administration of a tax Act; and (d) generally giving effect to the objects and purposes of tax administration."

22 Purposive interpretation gives effect to a meaning that best advances the fulfilment of the broader aims of a statute (Bastian Financial Services (Pty) Ltd $v$ General Hendrik Schoeman Primary School 20085 SA 1 (SCA) paras 17-20). Purpose is important to establish a context that clarifies the scope and intended effect of a law (Bertie van Zyl (Pty) Ltd v Minister of Safety and Security 20102 SA 181 (CC) para 21). Purpose is reflected in a statute's language read with its underlying policy or object, and its overall scheme and scope. Purpose is unrelated to parliamentary intention and must be distinguished from the mischief that a statute, or a provision in it, aims to overcome (Natal Joint Municipal Pension Fund $v$ Endumeni Municipality 20124 SA 593 (SCA) paras 21-23). For a summary of factors when ascertaining legislative purpose, see Minister of Land Affairs v Slamdien 19994 BCLR 413 (LCC) 422. Also see Goldswain 2008 MAR 107, 117-119.

23 By virtue of the TAA authorising inspections on "a random or a risk assessment basis" (s 40), two types of inspections are licensed, namely, random, routine, nontargeted inspections, and risk assessment-based, non-routine, targeted inspections. Both forms of inspection are means of testing compliance (Gaertner $v$ Minister of Finance 20141 SA 442 (CC) para 60). Clegg Concise Guide 86 explains "risk assessment" as referring "to the use of an analytic tool which profiles taxpayers according to the likelihood, on a statistical basis, that some or other shortfall exists in their tax affairs".

24 Section 14 reads: "Everyone has the right to privacy, which includes the right not to have- (a) their person or home searched; (b) their property searched; (c) their possessions seized; or (d) the privacy of their communications infringed." Phillips v DPP, Witwatersrand Local Division 20033 SA 345 (CC) para 19. For the constitutionality of s 45 vis a vis taxpayers' privacy, see Moosa 1996 Constitution and the Tax Administration Act 285-334, 379-445.

$26 \quad$ Magajane $v$ Chairperson, North West Gambling Board 20065 SA 250 (CC) para 59. It is unclear from the TAA whether $s 45$ inspections are regulatory or administrative. 
"search".27 When making this determination, relevant considerations include an inspection's aim, the legislation's underlying purpose, an affected person's privacy expectation, and the extent of the intrusion permitted by the statute, having regard to the nature and extent of the powers of inspection. ${ }^{28}$ See 4.1 below.

\subsection{Search: nature and extent}

The TAA does not confer a general power to conduct searches. ${ }^{29}$ Section 63 permits warrantless searches where performing them is reasonable or just, owing to alleged non-compliance with a duty or the commission of an offence. ${ }^{30}$ Thus, it licenses targeted, non-routine searches. The subject of section 63 is the gathering of taxpayer information, ${ }^{31}$ including "relevant material" defined as "any information, document or thing that in the opinion of SARS is foreseeably ${ }^{32}$ relevant for the administration of a tax Act as referred to in section $3 " .{ }^{33}$ When read with sections $6(1)^{34}$ and $63(2)(\mathrm{b})$ of the TAA, this definition shows that SARS's powers in section 63 are aimed at obtaining (reasonably) relevant (not necessary) ${ }^{35}$ information for the criminal and/or civil enforcement of tax laws. Thus, warrantless searches are conducted with the object inter alia of protecting and preserving the integrity, availability and/or accessibility of "relevant material". Ultimately,

27 See Mistry v Interim Medical and Dental Council of SA 19984 SA 1127 (CC) para 23.

28 Gupta 2013 NZJTLP 222, 226-235.

29 Croome and Olivier Tax Administration 163.

30 To be valid, a search does not need to relate to the investigation of a crime (South African Association of Personal Injury Lawyers v Heath 200010 BCLR 1131 (T) 1165).

$31 \quad$ "Taxpayer information" bears the meaning as defined in ss 1 read with $67(1)(b)$ of the TAA, namely, "any information provided by a taxpayer or obtained by SARS in respect of the taxpayer, including biometric information". Biometric information, as defined in $s 1$ of the TAA, encompasses intrusive biological data, such as, facial recognition, fingerprint recognition, voice recognition, and iris or retina recognition. For the constitutionality of the power to obtain intrusive biological data, see S v Huma 19952 SACR 411 (W). Clegg Concise Guide 85 warns: "'Forseeable' relevance is clearly in the eye of the beholder and may open the possibility of 'fishing expeditions' being undertaken through requests for information of no direct relevance to a particular line of enquiry." For a discussion of "relevant material", see Van der Walt 2015 https://sait.site$\mathrm{ym} . \mathrm{com} /$ news/212759/SARS-Information-gathering-powers-the-amended-

definition-of-relevant-material-.htm. Also see Vogelman and Muller 2014 ITJ 12. Section 6(1) reads: "The powers and duties of SARS under this Act may be exercised for purposes of the administration of a tax Act." In terms of $s$ 10(1) of the Interpretation Act 33 of 1957, a power "shall be performed from time to time as occasion requires". reads: "A senior SARS official may, if necessary or relevant to administer a tax Act, authorise an application for a warrant" (my emphasis) 
such operations aim to avoid harm to State fiscal interests caused by delay and/or by the loss of access to relevant material resulting from the strict adherence to formalities and legal niceties in the form of a warrant. ${ }^{36}$ In so doing, warrantless searches combat tax delinquency and promote the efficient and effective administration of tax. ${ }^{37}$

The question of what constitutes a "search" is a factual issue to be answered by adopting a common sense approach. In general terms, a search is "an examination of a person or property". ${ }^{38}$ As discussed below in 5.2 , during a search SARS officials can open anything and scour through personal possessions, including confidential communications. Also, they can conduct a body search, copy material, and remove and retain possession of computers and other storage devices. Thus, for TAA purposes a search may be described as "any act whereby a person, container or premises is visually or physically examined with the object of establishing whether an article is in, on or upon such person, container or premises". ${ }^{39}$

A search has the potential to cause hardship to a taxpayer through the institution of criminal or civil proceedings. ${ }^{40}$ Moreover, by its nature, a search infringes upon or threatens a range of fundamental rights (such as dignity, freedom, bodily security, privacy and property). ${ }^{41}$ This raises the question: Is a search under section 63 of the TAA a "search" envisaged by section 14

A fair balance must be struck between fiscal efficiency and general State interests, as well as taxpayers' rights (Goqwana v Minister of Safety 20161 All SA 629 (SCA) para 14).

Klue, Arendse and Williams Silke on Tax Administration para 8.6.2 contend that $\mathrm{s}$ 63 "assist in tax base broadening and addressing the reality that tax evaders who, upon approach by SARS, waste no time in destroying all records and evidence of their fraudulent activities and details of income derived". Keulder 2015 SALJ 820 writes: "The justification for a warrantless search is that it enables SARS to act straight away, thus preventing tax evaders from destroying or hiding evidence of their evasion. If SARS were required first to obtain a warrant, tax evaders would have the opportunity to destroy relevant documentation." Croome Taxpayers' Rights 142 states that the "power to search premises and seize documents is a necessary part of the Commissioner's armoury to ensure tax compliance". If documents are protected by privilege, then $s 64$ of the TAA applies. For the nature of privileged material, see Bogoshi $v$ Van Vuuren; Bogoshi $v$ Director, Officer for Serious Economic Offences 19961 SA 785 (A); Thint (Pty) Ltd v NDPP; Zuma v NDPP 2009 1 SA 1 (CC); A Company v CSARS 20144 SA 549 (WCC); South African Airways SOC v BDFM Publishers (Pty) Ltd 2016 JOL 35097 (GJ). Also see Croome and Olivier Tax Administration 168-185; Tiley 2002 CLJ 540. Gupta 2013 Australian Journal of Taxation 138. Mistry v Interim Medical and Dental Council of SA 19984 SA 1127 (CC) para 25; Platinum Asset Management (Pty) Ltd v Financial Services Board; Anglo Rand Capital House (Pty) Ltd v Financial Services Board 20064 SA 73 (W) para 127. 
of the Constitution? It is submitted that it is. ${ }^{42}$ This view is supported by section 63's using the same terminology as section 14 (quoted in $n$ 23), namely search and seize. ${ }^{43}$ Moreover, the nature and extent of the powers of entry, observation and removal exercisable at a search, discussed below in 5.2, bring a search within the remit of section 14. Consequently, section 63 restricts taxpayers' privacy as envisaged by the limitation clause in section 36(1) of the Constitution. To be valid, SARS's exercise of its powers of search and seizure must be justifiable in an open and democratic society based on human dignity, equality and freedom. ${ }^{44}$

\section{Powers exercisable at warrantless inspections and searches}

\subsection{Inspections}

Section 45 confers discretion ("may") 45 on a SARS official to conduct a warrantless inspection. Whereas section 45(2) confers the power of entry to premises albeit subject to an occupant's consent, section 45(1) makes no reference at all to the power of entry. ${ }^{46}$ This is noteworthy because, as

42 Sopinka J, in Baron v Canada 199313 CRR (2nd 65 (SCC) 84-85 describes the invasiveness of a search as follows: "Physical search of private premises ... is the greatest intrusion of privacy short of a violation of bodily integrity."

A seizure of property must, under $s 61(8)$ of the TAA, be for the investigative purposes specified there. "Seizure" is not a term of art. It implies "a forcible deprivation of possession" (Green $v$ Commissioner of Customs and Excise 1941 WLD 128 133). Also, see Naidoo v CIR 58 SATC 251 260. Since seizure entails the act of taking possession of an article discovered and its detention, its essence is the "effective deprivation of the owner's control" (Rudolph v CIR 19964 SA 552 (CC) para 11). The Court, in $R v$ Dyment 19882 SCR 417431 , defined the essence of a seizure as the "taking of a thing from a person by a public authority without that person's consent". Whether or not a deprivation is a seizure is a question of fact.

For the constitutionality of s 63 vis a vis taxpayers' privacy, see Moosa 1996 Constitution and the Tax Administration Act 285-334, 379-445.

45 For a discussion of the permissive roles of "may", see CIR v I H B King; CIR v A H King 19472 SA 196 (A) 209; MY Summit One: Farocean Marine (Pty) Ltd v Malacca Holdings (Pty) Ltd 20051 SA 428 (SCA) 439C. For the distinction between directory and peremptory provisions, see Sutter v Scheepers 1932 AD 163 173; Pottie v Kotze 19543 SA 719 (A) 725-726; Nkisimane v Santam Insurance Co Ltd 19782 SA 430 (A) 433H-434E; Prinsloo v Van der Linde 19973 SA 1012 (CC) para 13; Weenen Transitional Local Council v Van Dyk 20003 SA 435 (N) 442-445. For circumstances when "may" can mean "shall", see Stroud Riley \& Co Ltd v SIR 197436 SATC 143 (E) 151; Northwest Townships (Pty) Ltd v Administrator, Transvaal 19754 SA 1 (T) 12H-13A; South African Police Service v Public Servants Association 20073 SA 521 (CC) paras 14-20.

46 Section 63(1) of the TAA also omits stipulating that a senior SARS official may enter premises to conduct a search. It merely states that "the powers referred to in section 61(3)" may be exercised without a warrant. As is evident from 5.2 below, those powers do not expressly include an authority to enter premises. Subject to contextual changes, it is submitted that, by using the same reasoning adopted here in relation 
stated above, SARS is a creation of statute imbued with only those powers conferred statutorily. A purposive construction of section 45(1) indicates that the power of entry is implied therein. Unless this is so, its provisions would be ineffectual. This is because, but for the construction espoused here, inspections would be possible only under section 45(2), namely of those parts of a dwelling-house or domestic premises used for trade purposes. Such a state of affairs would undermine the attainment of the aim of section 45(1) discussed above in 4.1. Having regard to the common purpose of sections 45(1) and (2), logic dictates that the legislature must have intended to confer common powers to enable SARS to give effect to the aim of its provisions. This supports the view that the power of entry is implied into section 45(1). Furthermore, section $45(1)$ is the dominant or primary provision in section 45 . This is evident from its containing the jurisdictional requirements for conducting inspections under section 45(1) and (2). See para 5 below. Thus, it would be illogical if the power of entry were lacking from the dominant section 45(1) but was contained in section 45(2), a provision of secondary importance in the context of section 45.

Inspections are permitted at premises where a "trade or enterprise" is conducted. The TAA does not define "trade" or "enterprise" for its purposes. Section 1 states that for TAA purposes, "unless the context indicates otherwise, a term which is assigned a meaning in another tax Act has the meaning so assigned". The Income Tax Act ${ }^{47}$ and Value-Added Tax Act ${ }^{48}$ are "tax Act"s as defined in section 1 of the TAA. The former defines "trade",49 the latter defines "enterprise". ${ }^{50}$ There is no indication in the TAA that their meanings as defined in these tax Acts are inconsistent with their context in section 45 of the TAA. Thus, it is submitted that "trade" and

to $s 45(1)$, the power to enter premises is incorporated into $s$ 63(1) by necessary implication.

$47 \quad$ Income Tax Act 58 of 1962.

$48 \quad$ Value-Added Tax Act 89 of 1991.

49 Section 1 of the Income Tax Act 58 of 1962 defines "trade" as including "every profession, trade, business, employment, calling, occupation or venture, including the letting of any property and the use of or the grant of permission to use any patent as defined in the Patents Act or any design as defined in the Designs Act or any trade mark as defined in the Trade Marks Act or any copyright as defined in the Copyright Act or any other property which is of a similar nature".

50 In terms of $\mathrm{s} 1$ of the Value-Added Tax Act 89 of 1991, an "enterprise" means "any enterprise or activity which is carried on continuously or regularly by any person in the Republic or partly in the Republic and in the course or furtherance of which goods or services are supplied to any other person for a consideration, whether or not for profit, including any enterprise or activity carried on in the form of a commercial, financial, industrial, mining, farming, fishing, municipal or professional concern or any other concern of a continuing nature or in the form of an association or club". 
"enterprise" in section 45 bear the meanings ascribed in the Income Tax and Value-Added Tax Acts respectively.

Section 45(2) permits entry to "any part ... used for the purposes of trade". 51 No reference is made to an "enterprise". This raises the question: Can a SARS official enter a dwelling-house or domestic premises under section 45(2) where an enterprise is conducted? The answer depends on whether "trade" in section 45(2) encompasses an "enterprise". It is submitted that it does not. A narrow construction of "trade" in this context ought to be favoured because, first, it preserves and protects the right inter alia to privacy of a person carrying on an enterprise. This construction promotes the values of an open and democratic society based on human dignity, equality and freedom, which is an integral part of "spirit" of the Bill of Rights as contemplated by section $39(2)$ of the Constitution. ${ }^{52}$ Secondly, interpreting "trade" in section 45(2) as excluding an enterprise would align its meaning with that of "trade" as used in section 45(1). A construction that ensures that "trade" in section 45(2) is not broader in scope and ambit than in section 45(1) accords favourably with the presumption of interpretation that the same word in a statute bears the same meaning throughout, unless its context indicates otherwise. ${ }^{53}$

\subsection{Searches}

Under section 63(1) read with section 61(3) of the TAA, a SARS official has discretion ("may") at a warrantless search (i) to "open or cause to be opened or removed in conducting a search, anything which the official suspects to contain relevant material" (section 61(3)(a)), (ii) to "seize any relevant material" (section 61(3)(b)), (iii) to "seize and retain a computer or storage device in which relevant material is stored for as long as it is necessary to copy the material required", such as, iPhones, smart phones and cell phones (section 61(3)(c)), (iv) to "make extracts from or copies of relevant material, and require from a person an explanation of relevant material" (section 61(3)(d)), (v) if the premises is a vessel, aircraft or vehicle, to "stop and board the vessel, aircraft or vehicle, search the vessel, aircraft or vehicle or a person found in the vessel, aircraft or vehicle, and question the person with respect to a matter dealt with in a tax Act" (section 61(3)(e)),

$51 \quad$ For the meaning of "for purposes of trade", see De Beers Holdings (Pty) Ltd $v$ CIR 19861 SA 8 (A) 35-37; Solaglass Finance Co (Pty) Ltd v CIR 19912 SA 257 (A) 271-272; Burgess v CIR 19934 SA 161 (A) 179-182.

52 Section 39(2) of the Constitution of the Republic of South Africa, 1996 (the Constitution) reads: "When interpreting any legislation ... every court, tribunal or forum must promote the spirit, purport and objects of the Bill of Rights."

53 S v Dlamini; S v Dladla; S v Joubert; S v Schietekat 19994 SA 623 (CC) para 47. 
and (vi) to "search a person if the official is of the same gender as the person being searched" (section 61(5)).

The guidelines for the execution of a warrantless search are, in terms of section 63(3), contained in sections 61(4)-(8) of the TAA. They include that an inventory be made of all relevant material seized and a copy be provided to the person whose premises were searched (section 61(4)), and that every search occurs with strict regard for decency and order (section 61(5)). The latter provision is designed to respect and protect an affected person's fundamental rights to human dignity and bodily integrity. In terms of section 61(6), a search may occur with the assistance of a police officer who is obliged to acquiesce in a request by SARS ("must render the assistance").

Under section 61(7), no person may "obstruct a SARS official or a police officer" from executing a search, or "without reasonable excuse refuse to give such assistance as may be reasonably required". Although "assistance" is not defined for TAA purposes, the nature thereof would entail performing acts of the kind referred to in section 49(1), namely, "making available appropriate facilities, ${ }^{54}$ to the extent that such facilities are available", "answering questions", and "submitting relevant material as required". In terms of section 234 of the TAA, it is an offence for anyone to "wilfully and without just cause" refuse or neglect to "furnish, produce or make available any information, document or thing" (section 234(h)(i)), or to obstruct or hinder a SARS official in the discharge of official duties (section $234(k)$ ), or refuse to give assistance as required by section 49(1) (section 234(I)). ${ }^{55}$

Section 63 contains a contradiction. Whereas section 63(1) empowers a "senior SARS official" to conduct a search, section 63(2) and (4) refers to a "SARS official"56 carrying out a search. A SARS official and senior SARS

54 "Appropriate facilities" are those required for "effective, suitable, proper or fitting" (Economic Freedom Fighters $v$ Speaker of the National Assembly; Democratic Alliance $v$ Speaker of the National Assembly 20163 SA 580 (CC) para 71) execution of SARS's duties. Thus construed, "appropriate facilities" would, depending on circumstances, include a toilet, scanner, fax machine, computer, telephone, USB device, internet, email, photocopier, and access to a work station, lighting, water and electricity.

55 In terms of s 8(2) of the TAA, when exercising any power, such as an inspection or search, a SARS official must produce an identity card upon request by any affected person. Failure to do so would, under section 8(3), entitle the requester "to assume that the person is not a SARS official" and thus refuse entry to the requester's premises and justifiably withhold co-operation. employee of SARS; or (c) a person contracted or engaged by SARS, other than an external legal representative, for purposes of the administration of a tax Act and who 
official are distinguishable functionaries created by the TAA specifically for its purpose. Except for the Commissioner of SARS, who is included in the definition of both terms in section 1 of the TAA, every other category of "SARS official" is not a "senior SARS official" but may be conferred the latter designation. ${ }^{57}$ Therefore, a SARS official as defined may not exercise the powers in section 63(1) read with section 61(3) unless he/she is also a senior SARS official. ${ }^{58}$ Section 6(4) of the TAA permits "a SARS official under the control of" a senior SARS official to execute "a task ancillary to a power or duty" to be exercised by a senior SARS official. This provision does not, it is submitted, resolve the contradiction in section 63. This is so because, in relation to section 63(1), the authority conferred by section 6(4) applies only to the execution of tasks that are "ancillary to a power" exercised by a senior SARS official under sections 63(1) read with 61(3). In other words, section 6(4) does not grant a SARS official the powers listed in section 61(3) for the purpose of effecting a warrantless search. This contradiction may be resolved by applying the rules of statutory interpretation. It is submitted that the reference in sections 63(2) and (4) to a "SARS official" ought to be read as meaning such a SARS official who also qualifies as a senior SARS official. This result promotes the purpose of the provision and aligns with the context of these subsections when read with the other relevant TAA provisions referred to here. ${ }^{59}$

\section{Jurisdictional requirements for warrantless inspections and searches}

The powers conferred by sections 45 and 63 are designed inter alia to combat the mischief of taxpayer dishonesty and delinquency that is prejudicial to the fiscus. Since the powers are conferred for public benefit,

carries out the provisions of a tax Act under the control, direction or supervision of the Commissioner".

Moosa 2012 SA Merc LJ 344-345. The TAA sets no criteria, such as age, rank, status, qualification, knowledge, expertise or years of experience, for anyone to have the "senior SARS official" designation. In terms of ss 6(3)(a), (b) and (c), the powers and duties of a senior SARS official may be exercised by (i) Commissioner of SARS, (ii) a SARS official who has "specific written authority from the Commissioner to do so", or (iii) a SARS official "occupying a post designated by the Commissioner in writing for this purpose". Moosa 2012 SA Merc LJ 344-345. See also Keulder 2015 SALJ 843; Bovijn and Van Schalkwyk 2012 Stell LR 511.

59 Sections 45 and 63 do not empower SARS officials to (i) intercept communications, (ii) engage in eavesdropping or electronic surveillance, or (iii) "tap" a telephone by planting a bug or other listening device. Such conduct would be an actionable invasion of a taxpayer's privacy. 
they must be exercised in the public interest and not on a whim. ${ }^{60}$ Good cause must exist when the powers are exercised. If absent, or it cannot be shown to have existed when an inspection or search occurred, then there would be little substance left of a taxpayer's privacy. ${ }^{61}$ This is antithetical to the Constitution, which places a high premium on the protection, promotion, preservation and fulfilment of all fundamental rights.

Sections 45 and 63 impose good cause criteria for a lawful inspection and search respectively. These will now be discussed.

\subsection{Good cause under section 45}

Under section 45(1), an inspection may occur if "reasonable belief" exists that a trade or enterprise "is being carried on" at the place where an inspection will occur. Section 45(1) does not require a reasonable belief or suspicion that the occupant of the premises is unregistered for tax or noncompliant with sections 29 and/or 30 of the TAA. An inspection will not be rendered unlawful if it reveals that a trade or enterprise is not being carried on at the premises: Provided the SARS official who exercised the discretion under section 45(1) was privy to facts that led to a reasonable belief that a trade or enterprise was being conducted there. If this belief is later found to be misplaced, then this fact alone would not justify declaring the inspection unlawful. Although section 45(2) does not refer to the reasonable belief criterion, uniformity in the application of tax laws, a component of the rule of law, justifies this triggering requirement applying equally to section 45(1) and (2).

"Reasonable belief", and its variants "reasonable grounds to believe"62 and "reasonable grounds is satisfied", ${ }^{63}$ are objective standards. The

60 Police and Prisons Civil Rights Union v Minister of Correctional Services 20062 All SA 175 (E) para 53.

61

Investigating Directorate: Serious Economic Offences v Hyundai Motor Distributors (Pty) Ltd: In re Hyundai Motor Distributors (Pty) Ltd v Smit 20011 SA 545 (CC) para 54.

The criterion "reasonable grounds to believe" is used in the TAA in ss 60(1) (issuance of a search warrant) and in 62(1) (search of premises not identified in a warrant). For a discussion thereof, see Bovijn and Van Schalkwyk 2012 Stell LR 512513. Kubushi J, in Huang v CSARS: In re CSARS v Huang 201577 SATC 283 (GP) para 46, held: "That reasonable grounds must be established does not mean prima facie proof. What is of importance is that on the total picture presented by SARS ... reasonable grounds to believe that the applicants had failed to comply with their obligations under the tax Acts or had committed offences under those Acts, were established." 226 (T) 228A-B; ITC 147052 SATC 88 92; Farjas (Pty) Ltd $v$ Regional Land Claims 
reasonable belief standard has not yet been judicially considered in its context in section 45. As regard its possible meaning, the following dictum per Plasket $\mathrm{J}$ in NDPP $v$ Stander 64 is instructive:

It is clear from the cases that reason to believe that a state of affairs exists involves an objectively justifiable belief - 'a belief based on reason' in which a 'factual basis for the reason' exists. There must, in other words, be 'grounds, or facts, which give rise to, or form the basis of, the belief' and they must be reasonable grounds. That the belief must be objectively rational (even ... when more subjective language is used in a statute) is now a constitutional imperative, flowing from the founding value of the rule of law.

Linguistically, the phrase "any part thereof used for purposes of trade" (section 45(2)) ought to be construed as "any part thereof currently being used for purposes of trade" at the time when the inspection occurs. This interpretation accords with the present tense of the phrase in section 45(1), namely, "a trade or enterprise is being carried on". Therefore, sections $45(1)$ and (2) envisage an ongoing business operation when the inspection occurs. On this basis, an inspection may not occur in relation to a business that is dormant, closed down, or otherwise non-operational. In these circumstances, the information gathering methods of sections $46,47,48$ and 52 may be used. If the business is simply temporarily not functional, such as for lunchtime or a public holiday or a weekend, then the inspection may occur, since the trade or enterprise "is being carried on", albeit not at the specific moment when the inspection commences. If a business has relocated, then an inspection must occur at the new premises where the business "is being carried on". Thus, it is a factual issue in each instance whether "a trade or enterprise is being carried on" at the place where an inspection occurs and whether an activity engaged in constitutes a "trade or enterprise".

\subsection{Good cause under section 63}

Section 63 authorises consensual and non-consensual warrantless searches. In terms of section 63(1)(a), a search may be conducted if "the

Commissioner, KwaZulu-Natal 19985 BCLR 579 (LCC) para 41. As regards proof of "satisfaction", see Natal Estates Ltd v CIR 19754 SA 177 (A) 208. In COT v CW (Pvt) Ltd 19902 SA 245 (ZS) 265D, "reasonable" was held to imply "intelligent care and deliberation". believe", see Bert's Bricks (Pty) Ltd $v$ Inspector of Mines, North West Region 2012 ZAGPPHC 11 (9 February 2012) para 10. In Hunter $v$ Southam Inc 198411 DLR (4th) 641 (SCC) 658, the Court held that a "reasonable belief that relevant evidence may be uncovered" constitutes "a very low standard that would validate intrusion on the basis of suspicion, and authorise fishing expeditions of considerable latitude". 
owner or person in control of the premises so consents in writing". 65 This provision applies to all "premises", 66 save for dwelling-houses and domestic premises $^{67}$ as these are dealt with under section 63(4). It permits searches of such parts thereof used for trade purposes if consent is granted by "the occupant". ${ }^{6}$ Under section 63(1)(b), a search may be conducted if, subjectively on reasonable grounds, a senior SARS official is satisfied that the requirements listed in sub-paragraphs (i), (ii) and (iii) are met. ${ }^{69}$ These are the good cause criteria which must be met for a lawful search to occur under section 63(1)(a) and (b). The disjunctive "or" between subsections (a) and (b) indicates that they apply as alternatives. They do not operate in a hierarchical fashion: subsection (b) is not available only if consent under subsection (a) is refused. Therefore, a senior SARS official has the discretion to implement section $63(1)(b)$ without first attempting to obtain consent under section 63(1)(a).

\subsubsection{Warrantless searches by consent}

Whereas section 63(1)(a) requires written consent, section 63(4) does not. Consequently, section 63(4) permits oral, implied and tacit consent. An unwritten consent creates fertile ground for disputes and uncertainty. A written consent is an objective fact reflecting an authorisation. The document serves as proof of consent. In cases of doubt, its wording may be construed to ascertain its underlying aim. Except for the formality that, for the purposes of section 63(1)(a), consent must be in writing, ${ }^{70}$ the TAA sets no other requirement for the granting of a valid consent. ${ }^{71}$ In this regard,

65 In terms of $\mathrm{s} 3$ of the Interpretation Act 33 of 1957, "writing" includes "typewriting, lithography, photography and all other modes of representing or reproducing words in visible form".

Section 1 of the TAA defines "premises" as including "a building, aircraft, vehicle, vessel or place".

For the meaning of "dwelling-house" and "domestic premises", see Moosa 2012 ITJ 3.

Sections 45(2) and 63(4) permit warrantless inspections and searches, respectively, of dwelling-houses and domestic premises with "the consent of the occupant". Neither requires written consent. Owing to their similarities, the submissions made in the discussion here apply, mutatis mutandis, to s 45(2). If section 63(1)(b)(i), (ii) or (iii) is not met then SARS's recourse is either to conduct a consensual search under $\mathrm{s} 63(1)(\mathrm{a})$, or to apply under $\mathrm{s} 59$ for the issuance of a judicial warrant.

The TAA does not specify the content of the consent. At a minimum, it ought to state the ambit of the premises which may be searched and that consent is given under $\mathrm{s}$ 63(1)(a). Proof of the objective written consent criterion "may be less onerous" than the subjective "reasonable grounds criterion" in s 63(1)(b) discussed below (Keulder 2015 SALJ 819 839).

71 For discussion of the general requirements for consent, see Bovijn and Van Schalkwyk 2012 Stell LR 511. Since courts are the arbiters of legality, any invalid acts will engender legal consequences until the act is set aside on judicial review 
certain considerations ought to apply. First, consent must stem from a designated person who is competent in law to grant consent. ${ }^{72}$ Secondly, owing to the importance of the document recording a consent, its implications for the rights of occupiers, the risks of abuse by SARS, and the need to minimise uncertainty and the potential for litigation, section 63(1)(a) ought to be construed as requiring signature for a valid consent, even if the consent is written by the person designated in section 63(1)(a). ${ }^{73}$ Thirdly, consent must be given freely and voluntarily and not induced by duress, fraud, misrepresentation or coercion. Fourthly, the consent given must be informed.

It is unclear whether, procedurally, consent must be given before a search commences, or if it may be given after the search starts but before its completion, or if consent may be given after completion of the search. Compliance with section 63(1)(a) ought to be regarded as met if the timing of consent is before a search commences, albeit in an oral form, provided the consent is later, at any time, reduced to writing. That this prescribed formality occurred after completion of the search ought not to vitiate an otherwise valid consent. This approach accords with a purposive interpretation of section 63(1).

Whilst section 63(1)(a) authorises consent by "the owner ${ }^{74}$ or person in control of the premises", neither term is defined in the TAA. Contextually,

(MEC for Health, Eastern Cape v Kirland Investments (Pty) Ltd 20143 SA 481 (CC) paras 100 103).

72 Neither s 63(1)(a) nor s 63(4) refers to the granting of consent by an agent of "the owner or person in control of the premises" or "the occupant" (as the case may be). If consent is invalid then entry to the premises is unlawful and the fruit of any search would be tainted. Under s 66(1), SARS can be requested to "return some or all of the seized material" and to "pay the costs of physical damage caused during the conduct of a search and seizure". If it refuses then, under s 66(2), an application may be brought for a court order obliging "the return of the seized material or payment of compensation for physical damage caused". Despite the llegality, SARS may, in terms of s 66(4), seek a court order authorising the retention of seized material or a copy of relevant material. Such an order may be granted if it is in the interests of justice. This is to be determined with reference to all legally relevant factors, including prejudice to any party, the reasonableness of SARS's explanation for noncompliance with the law, the competing rights and interests of the parties, and the effect on tax administration and the administration of justice if the order is not granted in SARS's favour.

73 Signature is an objective, reliable fact serving as concrete proof of consent. Strict formalities for a valid signature ought not to be required. Pencil signatures, signatures by initials or by means of a stamp, mark, or by a party's writing below a printed heading, ought to suffice. See Van Niekerk v Smit 19523 SA 17 (T) 25.

74 In terms of $s 6$ (b) of the Interpretation Act 33 of 1957, statutory words in the singular include the plural, unless a contrary intention appears. Contextually in s 63(1)(a), "the owner" bears its plural meaning, namely, "the owners". Therefore, if premises 
ownership is a formal, legal relationship between the consenting party and the premises for which consent to search is granted. It is submitted that "control", in the context of section 63(1)(a), refers to the ability of the grantor of consent to lawfully exercise a high degree of authority over the premises and, by extension, over the possessions and communications there. Generally, "control" may be legal or physical. ${ }^{75}$ The former refers to persons enjoying possessory rights (such as a licensee, hirer and lessee). Physical control refers to actual custody of property (such as a ship's captain, an employee, an office manager, property manager, and property agent). It is submitted that in section 63(1)(a), "person in control" applies to both categories of persons referred to here. Whether legal or physical control exists is a factual issue to be decided on merit in each case.

Under sections 45(2) and 63(4), a SARS official may not "enter a dwellinghouse or domestic premises ... without the consent of the occupant". ${ }^{76}$ The term "occupant" is undefined in the TAA. "Occupant" is utilised as a noun in sections 45(2) and 63(4). The Oxford Thesaurus ${ }^{77}$ defines "occupant" when used as a noun to mean "resident, inhabitant, owner, householder, tenant, renter, leaseholder, lessee, addressee". Based on this meaning, "the occupant" in sections 45(2) and 63(4) would include owners and persons in legal or physical control of premises in the sense explained above.

As a safeguard for privacy rights, "the occupant" ought to be construed to cover only persons occupying the part of a dwelling-house or domestic premises sought to be inspected or searched. This construction would ensure that no occupier may lawfully consent to the invasion of another occupier's privacy, unless the grantor of consent was duly authorised. Accordingly, the grantor of consent must be a person competent in law to give consent in the sense that he/she is empowered or entitled as of right to give consent that is binding on, and enforceable against, the person(s)

are co-owned then, on a strict interpretation of the TAA that makes no provision for consent by an agent, each co-owner must consent personally. Consent by one owner would not be binding on another, nor would it constitute consent by "the owner". It is consent by "an owner". A strict interpretation ought to be avoided. Common sense dictates that consent ought to be valid if granted by anyone authorised to do so on behalf of a designated person. This is because it caters for situations where a designated person is unavailable and ensures that s 63(1)(a) is workable in cases where "the owner" is a juristic person which, obviously, cannot act in person.

75 Cohen Commissioner's Powers to Access Information 30-31.

76 In accordance with s 6(b) of the Interpretation Act 33 of 1957 , contextually in ss 45(2) and 63(4), "the occupant" bears its plural meaning, namely "the occupants". The submission made above in $\mathrm{n} 73$ applies, mutatis mutandis, to "the occupant". Waite, Hollingworth and Marshall Oxford Paperback Thesaurus 573. 
whose home or property is inspected or searched, and/or whose possessions and/or communications may be seized.

Accordingly, it is submitted that "the occupant" refers to the occupier who is authorised to be on the premises and who, at the time of the inspection or search, habitually resides there. This construction is consistent with the reference to "the" occupant and not "an" or "any" occupant. Consequently, on the one hand, "the occupant" would exclude trespassers, land invaders, vagrants, squatters, visitors, contractors, guests, house-sitters and babysitters. On the other hand, a live-in worker (such as, a butler, domestic worker, housekeeper, nurse, or child carer) would be encompassed by "the occupant".

\subsubsection{Warrantless search on reasonable grounds}

Section 63(1)(b)(i), (ii) and (iii) prescribes narrowly stated jurisdictional limits for conducting non-consensual, warrantless searches. A senior SARS official has discretion ("may") to conduct a search without judicial oversight. This power is earmarked for exceptional or rare situations when an apprehension, premised "on reasonable grounds", exists that a decision has been taken (action is "imminent") to remove or destroy relevant material. Section 63(1)(b) enables SARS to react speedily to real, not illusory, situations that give rise to genuine, not fabricated or contrived, concerns about imminent, not far-off, dangers to tax administration as may be caused by probable, not speculative or conjectural, efforts to remove or destroy relevant material. SARS must prove that the jurisdictional facts are met for the lawful exercise of discretion under section $63(1)(b) .{ }^{78}$ If they are present, then a taxpayer or other affected person challenging the lawfulness of the search bears the onus to show that the discretion was exercised unlawfully. This is so, irrespective of whether or not an infringement of a right is at stake. ${ }^{79}$

Minister of Safety and Security $v$ Sekhoto 20115 SA 367 (SCA) para 45. A presumption operates that powers will be exercised fairly in all circumstances (Minister of Health $v$ New Clicks South Africa (Pty) Ltd 20062 SA 311 (CC) para 152). Failure to do so may be shown by proof that a decision was arrived at arbitrarily, capriciously, mala fide, due to an unwarranted adherence to a fixed principle, or in order to further an ulterior or improper purpose or motive. It may also be shown by proof that the administrator misconceived the nature of the discretion or power and took account of irrelevant considerations or ignored relevant ones, or that the decision is so grossly unreasonable as to justify an inference that the administrator failed to properly apply his mind to the issue at hand (Thint (Pty) Ltd $v$ NDPP; Zuma v NDPP 20091 SA 1 (CC) paras 91-93).

79 Minister of Safety and Security $v$ Sekhoto 20115 SA 367 (SCA) paras 37, 49-53. Harms DP held, at para 31, that if the aim, object or purpose of the exercise of a 
Linguistically, "imminent" provides no specificity as to the time that would need to pass for a reasonably foreseen danger to qualify as imminent. This creates a conundrum. Since no definitive time can be laid down for an event to be regarded as "imminent", the issue of whether a removal or destruction is imminent is a factual issue to be decided on merit in each case. In the context of section 63(1)(b)(i), it is submitted that "imminent" means "impending or threatening". ${ }^{80}$ This meaning has the effect that section $63(1)$ (b)(i) does not contemplate a clear and present danger but rather a probable and impending removal or destruction of relevant material, or the threat thereof that, if materialised, would undermine "the administration of a tax Act" as defined (see footnote 19 above). Imminent is also distinguishable from "immediate". Naturally, section 63(1)(b) applies if there may be an immediate removal or destruction of relevant material likely to be found on premises. However, the more stringent requirement of an immediate removal or destruction is not imposed by section 63(1)(b).

A grammatical and contextual interpretation of "may be" and "likely", as used in section 63(1)(b)(i), indicates that the words refer to measurements of expectation involving "a result that is probable, objectively considered". 81 When these words are viewed in the light of the phrase "reasonable grounds is satisfied", then the expectation must be "that which would reasonably be expected". ${ }^{82}$ Thus construed, the cumulative effect of "reasonable grounds is satisfied", "may be" and "likely" is that the circumstances to which they relate need not exist as concrete or absolute facts, nor do they later, at judicial review, need be shown to have existed when the discretion to conduct a search was exercised. In their contexts, they simply require a reasonable likelihood or probability, objectively considered with reference to credible facts, that a removal or destruction of "relevant material" is "imminent". Accordingly, a belief based on unfounded claims or unsubstantiated allegations, or on mere speculation or conjecture, would not suffice to trigger the lawful application of the invasive tool catered for by section 63(1)(b).

The intention with which a removal or destruction occurs is irrelevant. Of importance is that such acts relate to "relevant material" as defined. Section

discretion is lawful, then the existence of an ulterior motive ought not to taint the exercise of the power with nullity. For a criticism of the distinction between the "object" and "motive" of an act, see Neethling 2011 THRHR 665-668.

$80 \quad$ Bovijn and Van Schalkwyk 2012 Stell LR 512.

$81 \quad$ Transnet Ltd v SA Metal Machinery Co (Pty) Ltd 20061 All SA 352 (SCA) para 42. 
22(b) of the Criminal Procedure Act, ${ }^{83}$ which is substantially or materially similar in content to section 63(1)(b) of the TAA, was described in Raliphaswa $v$ Mugivhi4 as "designed to protect rights to privacy against abuse of power by members of the SAPS". ${ }^{85}$ By parity of reasoning, the requirements in section 63(1)(b)(i), (ii) and (iii) are internal limits aimed at protecting privacy and other inter-related, mutually supporting rights against abuse by SARS officials. Hence, strict compliance with the stipulations of section $63(1)(b)$ is required.

Non-satisfaction of the good cause criteria in section 63(1)(b) would render a search to be an unjustifiable violation of a taxpayer's privacy and other associated right (such as, property or dignity). ${ }^{86}$ Moreover, under section $35(5)$ of the Constitution, information obtained unlawfully will be inadmissible in criminal proceedings against a taxpayer if its admission "would render the trial unfair or otherwise be detrimental to the administration of justice". ${ }^{87}$ As regards its admissibility in civil proceedings, a judicial officer has the discretion to exclude unconstitutionally obtained evidence if the circumstances justify such a course. ${ }^{88}$ This determination must be made judiciously after taking into account all relevant facts and circumstances, including the nature of the evidence, the extent of a right's violation (if any), whether the evidence could be lawfully obtained, and if the evidence would in the ordinary course have been obtained lawfully. ${ }^{89}$

83 Criminal Procedure Act 51 of 1977. See Gaertner v Minister of Finance 20141 SA 442 (CC) para 73.

$84 \quad$ Raliphaswa v Mugivhi 20084 SA 154 (SCA) 159A.

85 The search and seizure powers in $s 63$, and the power of inspection in $s 45$, ought to be sufficiently circumscribed as regards timing, place and scope, because overbreadth must be avoided. First, overbreadth causes a failure to inform an occupier of the limits of an inspection or search. Secondly, overbreadth may leave an inspector without sufficient guidelines in accordance with which to conduct the inspection or search within legal limits. Thirdly, overbreadth permits greater privacy intrusions that extend beyond circumstances where the reasonable expectation of privacy, for example, is low, to situations where the reasonable expectation is high. See Magajane v Chairperson, North West Gambling Board 20065 SA 250 (CC) para 71.

The Court, in Government of the Republic of South Africa $v$ Grootboom 20011 SA 46 (CC) para 23, held: "All the rights in our Bill of Rights are inter-related and mutually supporting." Also see Case v Minister of Safety and Security; Curtis v Minister of Safety and Security 19963 SA 617 (CC) para 27. For further discussion, see Thint (Pty) Ltd v NDPP; Zuma v NDPP 20091 SA 1 (CC) paras 215-224. Also see De Vos 2011 TSAR 270-271, 274-279. der Merwe Principles of Evidence 264-266. See also De Vos 2011 TSAR 279-281. Fedics Group (Pty) Ltd v Matus 19982 SA 617 (C) para 92. 
The exercise of discretion under section 63(1)(b) is reviewable conduct under the Promotion of Administrative Justice Act. ${ }^{90}$ Any such review is also subject to the general principles of administrative law. ${ }^{91}$ A senior SARS official must apply his mind to the available facts in accordance with the "behests of the statute and the tenets of natural justice". ${ }^{92}$ This means that the discretion must be exercised within the limits of the empowering TAA provision and subject to the Constitution. ${ }^{93}$ To be lawful, the discretion must be exercised bona fide and judiciously by an impartial official acting independently. ${ }^{94}$ SARS also bears the onus to show that a rational connection exists between a search, on the one hand, and the governmental purpose or State interest served thereby on the other. In the absence of rationality, which must be determined objectively, ${ }^{95}$ a search would be arbitrary and inconsistent with the rule of law. In an evaluation of whether a senior SARS official acted rationally, the human rights context of the impugned decision is important. The more the decision interferes with a fundamental right(s), the greater the force of SARS's justification must be.

\section{Conclusion}

Sections 45 and 63 of the TAA facilitate the achievement of effective tax administration. However, this article demonstrates that the powers conferred thereby are to be exercised with due regard for taxpayers' fundamental rights to privacy, property and dignity, inter alia. This article

90 Promotion of Administrative Justice Act 3 of 2000.

91 Van Dorsten 2005 Taxpayer 212.

$92 \quad$ Metcash Trading Ltd v CSARS 20011 SA 1109 (CC) para 40.

93 Unconstrained discretionary powers violate the rule of law in the Constitution. See Dawood v Minister of Home Affairs; Shalabi v Minister of Home Affairs; Thomas v Minister of Home Affairs 20003 SA 936 (CC) para 47. It is a matter of interpretation whether limits exist on discretion. See Affordable Medicines Trust $v$ Minister of Health 20063 SA 247 (CC) para 36.

In a review of the exercise of discretion on the basis that the decision to search is unlawful, irrational, unreasonable or procedurally unfair, the taxpayer must identify both the facts upon which the cause of action is premised and the legal basis thereof. Generally, this requires an applicant to specify the PAJA provision(s) upon which reliance is placed. See CSARS v Prudence Forwarding (Pty) Ltd 201678 SATC 119 para 32. For a discussion of administrative reviews, see De Ville Judicial Review of Administrative Action 172-177.

95 Pharmaceutical Manufacturers Association of SA: In re Ex Parte President of the Republic of South Africa 20002 SA 674 (CC) paras 85-86. Harms DP, in Minister of Safety and Security $v$ Sekhoto 20115 SA 367 (SCA) para 39, held: "The standard is not breached because an officer exercises the discretion in a manner other than that deemed optimal by the court. A number of choices may be open to him, all of which may fall within the range of rationality. The standard is not perfection, or even the optimum, judged from the vantage of hindsight and so long as the discretion is exercised within this range, the standard is not breached." 
demonstrates further that, upon a careful analysis and comparison of sections 45 and 63, key differences exist in their substantive content and practical operation. These are: first, whereas the powers in section 45 are exercisable by a "SARS official" (as defined in the TAA), the powers in section 63 are exercisable by a "senior SARS official" (as defined in the TAA). Secondly, whereas section 63(1)(a) provides for a search with the written consent of the owner or person in control of the premises, no provision is made in section 45 for an inspection to occur with the written consent of anyone. Under section 45(2), entry to a part of a dwelling-house or domestic premises not used for trade purposes may occur with the oral, tacit or implied consent of the occupant thereof. Thirdly, whereas section 45 permits routine (non-targeted) and non-routine (targeted) inspections, section 63 permits only non-routine searches. Fourthly, whereas section 45 permits only the inspection of material, section 63 permits the search of "premises" as defined and the seizure of material. Fifthly, whereas section 45 does not permit the seizure of material, section 63 read with section 61(3) does. Sixthly, whereas an inspection may occur only at premises where "a trade or enterprise" is carried on, a search may occur at any premises, whether used for trade or non-trade purposes. Seventh, whereas a "reasonable belief that a trade ... is being carried on" is a pre-requisite for entry to a home without consent under sections 45(2), no such or similar requirement applies under section 63(4). Eighth, whereas section 45(1) only permits inspections at premises of a taxpayer whose tax affairs are to be checked for compliance, section 63 permits searches of premises of both the relevant taxpayer whose affairs are the subject of the search as well as third parties associated with the taxpayer. Ninth, whereas warrantless searches are permitted on the grounds of urgency and expediency in exceptional circumstances only, an inspection is warrantless under all circumstances.

Tenth, an inspection is geared to determine any of the facts listed in sections 45(1)(a), (b) and (c). An inspection does not occur because of a suspicion or belief of non-compliance with a tax obligation. However, the basis for a search under section 63 is an alleged failure to comply with a tax obligation, or the commission of a tax offence. Eleventh, unlike section 63(2), the provisions of section 45 do not require a SARS official to inform "the person occupying the premises" that the inspection is conducted under section 45, nor does it require such a person to be informed of the reason for the inspection. Twelfth, whereas section 45 fails to outline any procedural guidelines or directions for conducting an inspection, section 63(3) stipulates that the procedural and other guidelines in sections 61(4)-(8) 
apply to all warrantless searches. Finally, whereas section 61(3) provides some guidance as to the scope of the search and seizure powers exercisable under section 63, no guidance is given in the TAA as to the scope of the powers exercisable at an inspection under section 45 . These distinctions between sections 45 and 63 aid a better understanding of where the red lines are between their respective provisions.

\section{Bibliography}

\section{Literature}

Basdeo 2009 PELJ

Basdeo V "The Constitutional Validity of Search and Seizure Powers in South African Criminal Procedure" 2009 PELJ 307-331

Botha Statutory Interpretation

Botha CJ Statutory Interpretation: An Introduction for Students $5^{\text {th }}$ ed (Juta Cape Town 2012)

Bovijn and Van Schalkwyk 2012 Stell LR

Bovijn S and Van Schalkwyk L "Concerns Regarding New Search and Seizure Powers Granted to SARS in terms of the Tax Administration Act" 2012 Stell LR 507-526

Clegg Concise Guide

Clegg D Concise Guide to Tax Administration (LexisNexis Durban 2012)

Cohen Commissioner's Powers to Access Information

Cohen S The Commissioner's Powers to Access Information: A License to Fish (Master of Business dissertation Auckland University of Technology 2010)

Croome Taxpayers' Rights

Croome BJ Taxpayers' Rights in South Africa (Juta Cape Town 2010)

Croome and Olivier Tax Administration

Croome BJ and Olivier L Tax Administration $2^{\text {nd }}$ ed (Juta Cape Town 2015)

De Ville Constitutional and Statutory Interpretation

De Ville JR Constitutional and Statutory Interpretation (Interdoc Consultants South Africa 2000) 
De Ville Judicial Review of Administrative Action

De Ville JR Judicial Review of Administrative Action in South Africa (LexisNexis Durban 2005)

De Vos 2011 TSAR

De Vos WLR "Illegally or Unconstitutionally Obtained Evidence: A South African Perspective" 2011 TSAR 268-262

Goldswain 2008 MAR

Goldswain GK "The Purposive Approach to the Interpretation of Fiscal Legislation - the Winds of Change" 2008 MAR 107-121

Gupta 2013 Australian Journal of Taxation

Gupta R "Inland Revenue's Powers of Search and Seizure and Taxpayers' Constitutional Rights" 2013 Australian Journal of Taxation 133-160

Gupta 2013 NZJTLP

Gupta R "Rights against Unreasonable Search and Seizure in Tax: Canadian and New Zealand Approaches Compared" 2013 NZJTLP 222247

Keulder 2015 SALJ

Keulder C "What's Good for the Goose is Good for the Gander Warrantless Searches in terms of Fiscal Legislation" 2015 SALJ 819-848

Klue, Arendse and Williams Silke on Tax Administration

Klue S, Arendse JA and Williams RC Silke on Tax Administration (online version) (LexisNexis Durban 2015)

Moosa 2012 ITJ

Moosa F "A Warrantless Search of 'Premises' under the Tax Administration Bill" 2012 ITJ 3-9

Moosa 2012 SA Merc LJ

Moosa F "The Power to Search and Seize without a Warrant under the Tax Administration Act" 2012 SA Merc LJ 338-345

Moosa 1996 Constitution and the Tax Administration Act

Moosa F The 1996 Constitution and the Tax Administration Act 28 of 2011: Balancing Efficient and Effective Tax Administration with Taxpayers' Rights (LLD-dissertation University of the Western Cape 2017) 
Mosupa 2001 Stell LR

Mosupa F "Constitutional Validity of Search and Seizure Provisions: A Perspective on Section 74 of the Income Tax Act 58 of 1962" 2001 Stell LR 317-325

Neethling 2011 THRHR

Neethling $\mathrm{J}$ "The Supreme Court of Appeal Pronounces upon Arrest without a Warrant and the Bill of Rights" 2011 THRHR 660-668

Schwikkard and Van der Merwe Principles of Evidence

Schwikkard PJ and Van der Merwe SE Principles of Evidence $3^{\text {rd }}$ ed (Juta Cape Town 2010)

Tiley 2002 CLJ

Tiley J "Professional Privilege and the Tax Man" 2002 CLJ 540-543

Van Dijk Probe into the Constitutionality of Relevant Sections

Van Dijk EC A Probe into the Constitutionality of Relevant Sections of the Tax Administration Act (LLM-dissertation University of Pretoria 2014)

Van Dorsten 2005 Taxpayer

Van Dorsten JL "The Right to Reasons for Decisions in Taxation Matters Part II" 2005 The Taxpayer 206-214

Vogelman and Muller 2014 ITJ

Vogelman and Muller A "The Extensive Powers of SARS in Requesting 'Relevant Material'" 2014 ITJ 12-14

Waite, Hollingworth and Marshall Oxford Paperback Thesaurus

Waite M, Hollingworth L and Marshall D (eds) Oxford Paperback Thesaurus $3^{\text {rd }}$ ed (Oxford University Press Oxford 2006)

Zeffertt and Paizes South African Law of Evidence

Zeffertt DT and Paizes AP The South African Law of Evidence $2^{\text {nd }}$ ed (LexisNexis Durrban 2009)

\section{Case law}

A Company v CSARS 20144 SA 549 (WCC)

Affordable Medicines Trust v Minister of Health 20063 SA 247 (CC)

Ahmed v Minister of Home Affairs $2016 \mathrm{JOL} 36695$ (WCC) 
Aktiebolaget Hassle v Triomed (Pty) Ltd 20031 SA 155 (SCA)

AM Moolla Group Ltd v CSARS 2005 JOL 15456 (T)

Association of Amusement and Novelty Machine Operators $v$ Minister of Justice 19802 SA 636 (A)

Baron v Canada 199313 CRR $\left(2^{\text {nd }}\right) 65$ (SCC)

Bastian Financial Services (Pty) Ltd v General Hendrik Schoeman Primary School 20085 SA 1 (SCA)

Bato Star Fishing (Pty) Ltd v Minister of Environmental Affairs and Tourism 20044 SA 490 (CC)

Bertie van Zyl (Pty) Ltd v Minister of Safety and Security 20102 SA 181 (CC)

Bert's Bricks (Pty) Ltd $v$ Inspector of Mines, North West Region 2012 ZAGPPHC 11 (9 February 2012)

Bogoshi v Van Vuuren; Bogoshi v Director, Officer for Serious Economic Offences 19961 SA 785 (A)

Breitenbach v Fiat SA (Edms) Bpk 19762 SA 226 (T)

Burgess v CIR 19934 SA 161 (A)

Case v Minister of Safety and Security; Curtis $v$ Minister of Safety and Security 19963 SA 617 (CC)

CIR v I H B King; CIR v A H King 19472 SA 196 (A)

COT v CW (Pvt) Ltd 19902 SA 245 (ZS)

CSARS v Prudence Forwarding (Pty) Ltd 201678 SATC 119

Dawood v Minister of Home Affairs; Shalabi v Minister of Home Affairs; Thomas $v$ Minister of Home Affairs 20003 SA 936 (CC)

De Beers Holdings (Pty) Ltd v CIR 19861 SA 8 (A)

Department of Land Affairs v Goedgelegen Tropical Fruits (Pty) Ltd 20076 SA 199 (CC) 
Economic Freedom Fighters $v$ Speaker of the National Assembly; Democratic Alliance $v$ Speaker of the National Assembly 20163 SA 580 (CC)

Farjas (Pty) Ltd v Regional Land Claims Commissioner, KwaZulu-Natal 19985 BCLR 579 (LCC)

Fedics Group (Pty) Ltd v Matus 19982 SA 617 (C)

Ferucci v CSARS 20026 SA 219 (C)

Gaertner v Minister of Finance 20141 SA 442 (CC)

Goqwana v Minister of Safety 20161 All SA 629 (SCA)

Government of the Republic of South Africa v Grootboom 20011 SA 46 (CC)

Green v Commissioner of Customs and Excise 1941 WLD 128

Huang v CSARS: In re CSARS v Huang 201577 SATC 283 (GP)

Head of Department: Mpumalanga Department of Education v Hoërskool Ermelo 20102 SA 415 (CC)

Hunter v Southam Inc 198411 DLR (4th) 641 (SCC)

Investigating Directorate: Serious Economic Offences $v$ Hyundai Motor Distributors (Pty) Ltd: In re Hyundai Motor Distributors (Pty) Ltd v Smit 2001 1 SA 545 (CC)

ITC 147052 SATC 88

Magajane v Chairperson, North West Gambling Board 20065 SA 250 (CC)

Maphango v Aengus Lifestyle Properties (Pty) Ltd 20123 SA 531 (CC)

Master Currency (Pty) Ltd v CSARS 20133 All SA 135 (SCA)

MEC for Health, Eastern Cape v Kirland Investments (Pty) Ltd 20143 SA 481 (CC)

Metcash Trading Ltd v CSARS 20011 SA 1109 (CC)

Minister of Health v New Clicks South Africa (Pty) Ltd 20062 SA 311 (CC) 
Minister of Land Affairs v Slamdien 19994 BCLR 413 (LCC)

Minister of Safety and Security v Sekhoto 20115 SA 367 (SCA)

Mistry v Interim Medical and Dental Council of SA 19984 SA 1127 (CC)

MV Iran Dastghayb Islamic Republic of Iran Shipping Lines $v$ Terra-Marine SA 20106 SA 493 (SCA)

MY Summit One: Farocean Marine (Pty) Ltd v Malacca Holdings (Pty) Ltd 20051 SA 428 (SCA)

Naidoo v CIR 58 SATC 251

Natal Estates Ltd v CIR 19754 SA 177 (A)

Natal Joint Municipal Pension Fund v Endumeni Municipality 20124 SA 593 (SCA)

NDPP v Stander 20081 SACR 116 (E)

Nkisimane v Santam Insurance Co Ltd 19782 SA 430 (A)

Northwest Townships (Pty) Ltd v Administrator, Transvaal 19754 SA 1 (T)

Novartis v Maphil 20161 SA 518 (SCA)

Pharmaceutical Manufacturers Association of SA: In re Ex Parte President of the Republic of South Africa 20002 SA 674 (CC)

Phillips v DPP, Witwatersrand Local Division 20033 SA 345 (CC)

Platinum Asset Management (Pty) Ltd v Financial Services Board; Anglo Rand Capital House (Pty) Ltd v Financial Services Board 20064 SA 73 (W)

Police and Prisons Civil Rights Union v Minister of Correctional Services 20062 All SA 175 (E)

Pottie v Kotze 19543 SA 719 (A)

Prinsloo v Van der Linde 19973 SA 1012 (CC)

$R v$ Dyment 19882 SCR 417

$R v$ Jefferies 19941 NZLR 290 (CA) 
Raliphaswa v Mugivhi 20084 SA 154 (SCA)

Rudolph v CIR 19964 SA 552 (CC)

S v Dlamini; S v Dladla; S v Joubert; S v Schietekat 19994 SA 623 (CC)

$S$ v Huma 19952 SACR 411 (W)

S v Van Rooyen 20025 SA 246 (CC)

Sasria Ltd v Slabbert Burger Transport (Pty) Ltd 20085 SA 270 (SCA)

Solaglass Finance Co (Pty) Ltd v CIR 19912 SA 257 (A)

South African Airways SOC v BDFM Publishers (Pty) Ltd 2016 JOL 35097 (GJ)

South African Association of Personal Injury Lawyers v Heath 200010 BCLR 1131 (T)

South African Police Service v Public Servants Association 20073 SA 521 (CC)

Spring Forest Trading 599 CC v Wilberry (Pty) Ltd t/a Ecowash 20152 SA 118 (SCA)

Standard General Ins v Commissioner for Customs and Excise 20052 SA 166 (SCA)

Stroud Riley \& Co Ltd v SIR 197436 SATC 143 (E)

Sutter $v$ Scheepers 1932 AD 163

Thint (Pty) Ltd v NDPP; Zuma v NDPP 20091 SA 1 (CC)

Thoroughbred Breeders' Association v Price Waterhouse 20014 SA 551 (SCA)

Transnet Ltd v SA Metal Machinery Co (Pty) Ltd 20061 All SA 352 (SCA)

Van Niekerk v Smit 19523 SA 17 (T)

Weenen Transitional Local Council v Van Dyk 20003 SA 435 (N)

\section{Legislation}


Constitution of the Republic of South Africa, 1996

Criminal Procedure Act 51 of 1977

Electronic Communications and Transactions Act 25 of 2002

Income Tax Act 58 of 1962

Interpretation Act 33 of 1957

Promotion of Administrative Justice Act 3 of 2000

South African Revenue Service Act 34 of 1997

Tax Administration Act 28 of 2011

Value-Added Tax Act 89 of 1991

Internet sources

Van der Walt 2015 https://sait.site-ym.com/news/212759/SARSInformation-gathering-powers-the-amended-definition-of-relevant-material.htm

Van der Walt J 2015 SARS' Information-Gathering Powers, the Amended Definition of "Relevant Material" https://sait.siteym.com/news/212759/SARS-Information-gathering-powers-the-amendeddefinition-of-relevant-material-.htm accessed 4 February 2015

\section{List of Abbreviations}

CLJ

CIR

CSARS

DPP

ITJ

MAR

NDPP

NZJTLP

PAJA

PELJ

SALJ
Cambridge Law Journal

Commissioner for Inland Revenue

Commissioner of the South African Revenue Service

Director of Public Prosecutions Insurance and Tax Journal Meditari Accountancy Research National Director of Public Prosecutions New Zealand Journal of Taxation Law and Policy

Promotion of Administrative Justice Act Potchefstroom Electronic Law Journal South African Law Journal 
SA Merc LJ

SAPL

SARS

SARS Act

Stell LR

TAA

THRHR

TSAR
South African Mercantile Law Journal

Southern African Public Law

South African Revenue Service

South African Revenue Service Act

Stellenbosch Law Review

Tax Administration Act

Tydskrif vir die Hedendaagse Romeinse-

Hollandse Reg

Tydskrif vir die Suid-Afrikaanse Reg 